\title{
PENGARUH KEADILAN ORGANISASIONAL TERHADAP PERILAKU KERJA KONTRA PRODUKTIF DAN DAMPAKNYA PADA KEPUASAN KERJA PEGAWAI DINAS SOSIAL PROVINSI KALIMANTAN BARAT
}

\author{
Iryansah a \\ *abc Magister Manajemen, Fakultas Ekonomi dan Bisnis, Universitas Tanjungpura, \\ Pontianak \\ *Email : iryan.pnk@gmail.com \\ (Diterima Desember 2019; Disetujui Juni 2020; Dipublikasikan Juli 2020)
}

Abstrak

\begin{abstract}
This research was conducted with the aim of testing and analyzing the effect of organizational justice on counterproductive work behavior and its impact on job satisfaction of West Kalimantan Provincial Social Service Employees. This type of research is a survey using a quantitative approach. The population in this study were all ASN at the Social Service of West Kalimantan Province, amounting to 85 people. The research data were processed and analyzed using the path analysis model (SPSS 18). Based on the hypothesis testing it was concluded that distributive justice and interactional justice had a negative and not significant effect on counterproductive work behavior, while procedural justice had a negative and significant effect on counterproductive work behavior. The results of hypothesis testing further indicate that distributive justice, procedural justice, and interactional justice have positive and significant effects on job satisfaction, while counterproductive work behavior has a negative and significant effect on job satisfaction.
\end{abstract}

Keyword : Distributive justice, procedural justice,interactional justice, counterproductive work behavior and job

\section{PENDAHULUAN}

Sumber daya manusia merupakan bagian penting dalam perusahaan atau organisasi, sehingga jika tidak dikelola dengan baik tujuan dari perusahaan atau organisasi tidak akan tercapai. Masalah yang terjadi adalah sulitnya menemukan sumber daya manusia yang profesional dan berkualitas. Jika permasalahan tersebut tidak mampu diatasi oleh perusahaan atau organisasi akan berdampak negatif terhadap produktifitas, efisiensi dan daya saing (Rayadi, 2012). Perilaku kerja kontraproduktif merupakan suatu tindakan sengaja atau sadar yang dilakukan oleh pekerja dan dapat menyebabkan kerugian bagi perusahaan atau organisasi(Budiman, 2015). Perilaku kerja kontraproduktif merupakan perilaku yang akan membahayakan suatu organisasi dan perusahaan dalam segala aspek (Oge et al, 2015). Selainitu, Wahyuni dan Nugraheni (2016) menyatakan bahwa perilaku kerja kontraproduktif secaraumum dapat mengganggu organisasi melalui dampak langsung pada fungsi organisasi serta kerugian yang sangat tinggi. 
Perilaku kerja kontraproduktif yang terjadi di kalangan ASN terkait erat dengan DisiplinPegawai Negeri Sipil. Dalam Peraturan Pemerintah Republik Indonesia Nomor 53 Tahun 2010 tentang Disiplin Pegawai Negeri Sipil, disebutkan bahwa pelanggaran disiplin yang dilakukanoleh Pegawai Negeri Sipil (PNS) akan dijatuhi hukuman sesuai dengan tingkat dan jenis disiplin. Meskipun demikian, setiap PNS yang melanggar peraturan disiplin masih tetap dapatmelakukan upaya administratif sebagai bentuk keberatan atas ketidakpuasan terhadap hukuman yang telah diputuskan dan dijatuhkan kepada PNS yang bersangkutan. Adanya upaya administratif tersebut dinilai dapat menyebabkan prosedur hukuman disiplin menjadi lebih longgar sehingga hal ini membuat ASN di Indonesia banyak yang terlibat dalam perilakukerja kontraproduktif.

judul "Pengaruh Keadilan Organisasional Terhadap Perilaku Kerja Kontra Produktif dan Dampaknya pada Kepuasan Kerja Pegawai Dinas Sosial Provinsi Kalimantan Barat".

\section{RUMUSAN MASALAH}

Berdasarkan pernyataan masalah penelitian yang telah dikemukakan, maka pertanyaan masalah penelitian ini adalah sebagai berikut:

1. Apakah keadilan distributif, keadilan prosedural, dan keadilan interaksional berpengaruh terhadap perilaku kerja kontra-produktif pegawai di Dinas Sosial Provinsi Kalbar?

2. Apakah keadilan distributif, keadilan prosedural, keadilan interaksional, dan perilaku kerja kontraproduktif berpengaruh terhadap kepuasan kerja pegawai di Dinas Sosial Provinsi Kalbar?

3. Apakah Perilaku Kerja Kontraproduktif berpengaruh sebagai variabel yang memediasi pengaruh keadilan distributif, keadilan prosedural, dan keadilan interaksional terhadap kepuasan kerja pegawai di Dinas Sosial Provinsi Kalbar?

\section{TUJUAN PENELITIAN}

Dari perumusan masalah di atas, maka penelitian ini bertujuan sebagai berikut:

1. Untuk mengetahui dan menganalisis pengaruh keadilan distributif, keadilan prosedural, dankeadilan interaksional terhadap perilaku kerja kontraproduktif pegawai di Dinas Sosial Provinsi Kalbar.

2. Untuk mengetahui dan menganalisis pengaruh keadilan distributif, keadilan prosedural, keadilan interaksional, dan perilaku kerja kontraproduktif terhadap kepuasan kerja pegawai di Dinas Sosial Provinsi Kalbar. 
3. Untuk mengetahui dan menganalisis pengaruh Perilaku Kerja Kontraproduktif sebagai variabel yang memediasi pengaruh keadilan distributif, keadilan prosedural, dan keadilan interaksional terhadap kepuasan kerja pegawai di Dinas Sosial Provinsi Kalbar.

\section{KAJIAN LITERATUR}

\section{KEADILAN ORGANISASI}

Keadilan organisasi adalah bagian terpenting bagi sebuah organisasi untuk dapat mencapai target dan membentuk strategi agar tujuan organisasi dapat tercapai (Guven \& Gursoy, 2014). Karyawan menggunakan istilah keadilan organisasi untuk menggambarkan suatu keadilan yang berlangsung di lingkungan organisasi (Alzubi, 2010). Sedangkan Gillilannd \& Chand (dalam Anderson, 2005) menyebutkan bahwa keadilan organisasi merupakan kesetaraan yang dirasakan oleh karyawan dalam mempersepsikan keadilan yang diputuskan oleh organisasi. Hal tersebut di dukung oleh penyataan yang dikemukakan Irwandi \& Puspitadewi (2012) yang mendefinisikan keadilan organisasi sebagai pandangan atau perasaan pegawai terhadap diri sendiri dan orang lain mengenai hasil keputusan yang diambil. Berbeda dengan penyataan yang dikemukakan oleh Dundar \& Tabancali (2012) mendefinisikan keadilan organisasi merupakan imbalan dan hukum yang diberikan organisasi melalui aturan atau keputusan yang diumumkan sebagai interaksi antara karyawan dan organisasi.

\section{PERILAKU KERJA KONTRAPRODUKTIF}

Perilaku kerja kontraproduktif merupakan perilaku yang dilakukan oleh anggota organisasi secara sukarela dan mempengaruhi prestasi kerja serta melemahkan efektivitas organisasi (Lau Au \& Ho, 2003). Gruys \& Sackett (2003) mengemukakan bahwa perilaku kerja kontraproduktif dilakuan dengan sengaja oleh anggota organisasi yang dipandang organisasi sebagai perilaku yang bertentangan dengan kepentingan yang sah. Pernyataan tersebut serupa dengan pernyataan yang dikemukakan oleh Goh at. el, (2006) menambahkan bahwa perilaku kerja kontraproduktif memiliki dampak kerugian pada organisasi dan anggota organisasi. Perilaku kerja kontraproduktif merupakan perilaku kerja yang sangat mengganggu kinerja organisasi secara umum dan penurunan produktivitas kerja karyawan secara khususnya (Rusdi, 2015). Selain itu, Perilaku kerja kontraproduktif dapat mengganggu organisasi secara langsung pada fungsi organisasi atau dengan menyakiti anggota kerja dengan tujuan untuk menurunkan keefektifan kerja karyawan (Wahyuni \& Nugraheni, 2016). Fox at. al. (2001) mendefinisikan bahwa perilaku kerja kontraproduktif merupakan perilaku yang dilakukan oleh karyawan dengan efek yang dapat merugikan organisasi dan anggota kerja. Perilaku kerja kontraproduktif menjadi jenis perilaku kerja yang menyimpang dengan maksud menyakiti organisasi dan anggota organisasi (Bai at. el. 2016).

\section{KEPUASAN KERJA}


Robbins \& Judge (2013) memberikan definisi kepuasan kerja sebagai "a positive feelings about a job resulting from an evaluation of its characteristics" (perasaan positif tentang pekerjaan sebagai hasil evaluasi dari karakteristiknya). Sedangkan menurut McShane \& Glinow (2003) menyatakan bahwa "job satisfaction represents a person's evaluation of his or her job and work context" (kepuasan kerja merupakan evaluasi seseorang terhadap pekerjaan dan konteks pekerjaannya). Priansa (2016) menyatakan bahwa kepuasan kerja merupakan "sekumpulan perasaan pegawai terhadap pekerjaannya, apakah senang/suka atau tidak senang/tidak suka sebagai interaksi pegawai dengan lingkungan pekerjaannya atau sebagai persepsi sikap mental, juga sebagai hasil penilaian pegawai terhadap pekerjaannya".

Dapat disimpulkan bahwa kepuasan kerja adalah seperangkat perasaan karyawan tentang hal- hal yang menyenangkan atau tidak terhadap suatu pekerjaan yang mereka hadapi.

\section{KERANGKA PEMIKIRAN DAN HIPOTESIS}

Berdasarkan tinjauan pustaka, penelitian terdahulu dan hubungan antar variabel maka dapat disusun suatu kerangka pemikiran dalam penelitian ini, seperti yang disajikan dalam gambar berikut:

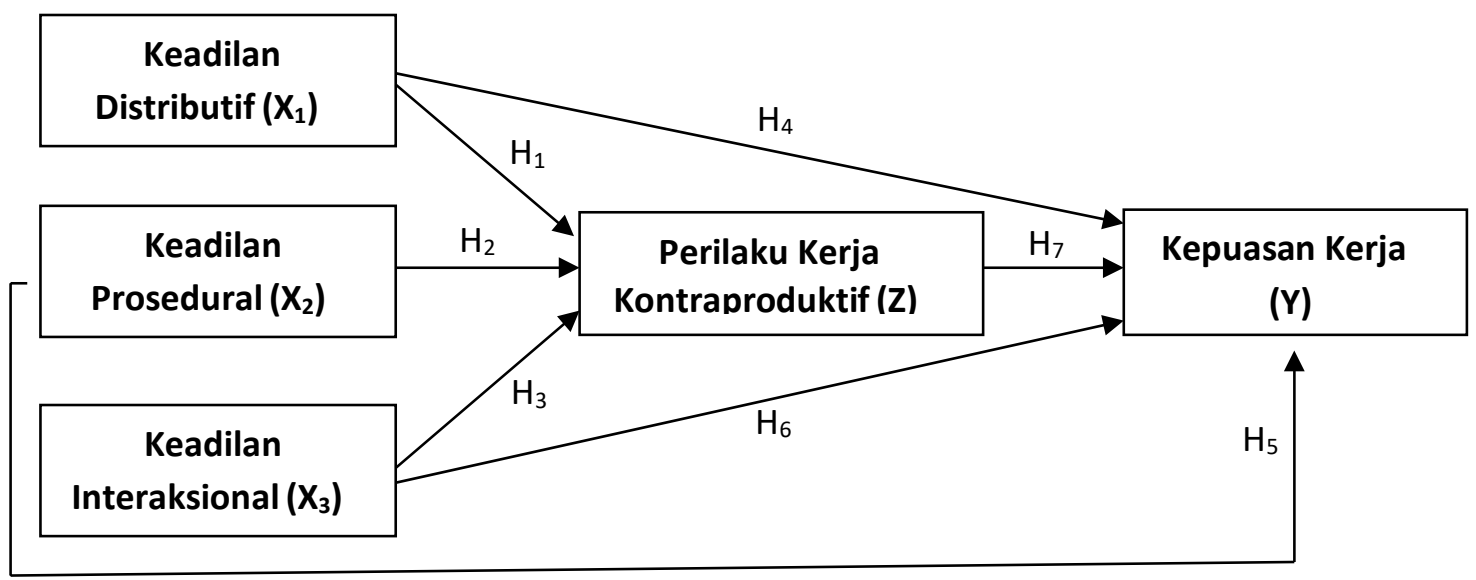

Gambar 1 Kerangka Konseptual Penelitian

Berdasarkan hubungan-hubungan teoritis yang dipaparkan di atas, maka dapat dirumuskan beberapa hipotesis sebagai berikut:

1. Keadilan distributif, keadilan prosedural, dan keadilan interaksional berpengaruh secara positif dan signifikan terhadap perilaku kerja kontraproduktif pegawai Dinas Sosial Provinsi Kalimantan Barat.

2. Keadilan distributif, keadilan prosedural, keadilan interaksional, perilaku kerja kontraproduktif berpengaruh secara positif dan signifikan terhadap kepuasan kerja pegawai Dinas Sosial Provinsi Kalimantan Barat. 
3. Perilaku kerja kontraproduktif berpengaruh sebagai variabel yang memediasi pengaruh keadilan distributif, keadilan prosedural, dan keadilan interaksional terhadap kepuasan kerja pegawai Dinas Sosial Provinsi Kalimantan Barat.

\section{METODE PENELITIAN}

Penelitian menggunakan eksplanatori (explanatory research). Menurut Sugiyono (2016) penelitian eksplanatori adalah penelitian yang menjelaskan hubungan kausal antara variabel atau untuk mengetahui dan menjelaskan pengaruh antar variabel yang ada dan dilanjutkan dengan pengujian hipotesis. Teknik pengumpulan data yang dilakukan dengan kuesioner, observasi, dan studi pustaka. Populasi dari penelitian penelitian ini merupakan seluruh ASN pada Dinas Sosial Provinsi Kalimantan Barat yang berjumlah 85 orang.

Pengambilan sampel pada penelitian ini menggunakan sensus. Teknik analisis data yang digunakan dalam penelitian ini adalah uji validitas dan reliabilitas, uji asumsi klasik yang terdiri dari uji normalitas dan linieritas, analisis jalur (path analysis), serta pengujian hipotesis dengan menggunakan uji secara simultan (Uji F), uji secara parsial (Uji t), dan koefisien determinasi.

\section{PENELITIAN DAN PEMBAHASAN}

Analisis Jalur (Path Analysis)

Pengujian hipotesis dilakukan dengan analisis jalur (path analysis). Menurut Ghozali (2013) analisis jalur adalah penggunaan analisis regresi untuk menaksirkan hubungan kausualitas antar variabel (model casual) yang telah ditetapkan sebelumnya berdasarkan teori. Analisis jalur digunakan untuk melukiskan dan menguji hubungan antar variabel yang berbentuk sebab akibat (bukan bentuk hubungan interaktif atau reciprocal). Dari diagram jalur akan didapatkan hubungan langsung atau tidak langsung antar variabel. Hasil pengolahan data dengan menggunakan SPSS selengkapnya ada pada sebagai berikut :

\section{a. Substruktur Pertama}

Analisis mengenai substruktur pertama dapat diketahui pada Tabel 1 berikut:

Tabel 1

Hasil Uji Hipotesis Persamaan Substruktur Pertama Coefficients $^{\mathbf{a}}$

\begin{tabular}{|c|c|c|c|c|c|c|}
\hline & & \multicolumn{2}{|c|}{$\begin{array}{c}\text { Unstandardized } \\
\text { Coefficients }\end{array}$} & $\begin{array}{c}\text { Standardized } \\
\text { Coefficients }\end{array}$ & \multirow[b]{2}{*}{$\mathrm{t}$} & \multirow[b]{2}{*}{ Sig. } \\
\hline \multicolumn{2}{|c|}{ Model } & $\mathrm{B}$ & Std. Error & Beta & & \\
\hline & (Constant) & 42.127 & 6.720 & & 6.269 & .000 \\
\hline & Keadilan Distributif (X1) & -.300 & .250 & -.130 & -1.199 & .234 \\
\hline & Keadilan Prosedural (X2) & -.456 & .166 & -.285 & -2.740 & .008 \\
\hline & & & $\begin{array}{r}\text { *correspon } \\
\text { Online } \\
\text { DOI : }\end{array}$ & $\begin{array}{l}\text { ding authors e-ma } \\
\text { ISSN: } 2721-4230 \\
\text { http://dx.doi.org/1 }\end{array}$ & $\begin{array}{l}\text { ryan.pnk } \\
\text { rint ISSN } \\
\text { 6418/ejm }\end{array}$ & $\begin{array}{l}\text { mail.com } \\
21-4281 \\
8 \mathrm{i} 3.43636 \\
\end{array}$ \\
\hline
\end{tabular}


Keadilan Interaksional (X3)

$-.295$

.183

$-.172-1.616$

.110

a. Dependent Variable: Perilaku Kerja Kontraproduktif (Z)

Sumber:Hasil Pengolahan Data, 2020

Dari Tabel 1 diketahui bahwa persamaan substruktur pertama adalah sebagai berikut : Z = -0,130 X1- 0,285 X2- 0,172 X3+ 1 1.

1) Uji Pengaruh Simultan.

Uji pengaruh simultan adalah untuk mengetahui seberapa jauh semua variabel bebas yang dimasukkan dalam model mempunyai pengaruh secara bersama-sama terhadap variabel terikat. Hasil pengujian dari hipotesis terlihat pada Tabel 2 sebagai berikut:

Tabel 2

Model ANOVA Persamaan Substruktur Pertama ANOVAb

\begin{tabular}{|ll|r|r|r|r|r|}
\hline Model & & Sum of Squares & Df & Mean Square & \multicolumn{1}{c|}{ F } & \multicolumn{1}{c|}{ Sig. } \\
\hline 1 & Regression & 225.513 & 3 & 75.171 & 5.060 & $.003^{\mathrm{a}}$ \\
& Residual & 1203.240 & 81 & 14.855 & & \\
& Total & 1428.753 & 84 & & & \\
\hline
\end{tabular}

a. Predictors: (Constant), Keadilan Interaksional (X3), Keadilan Prosedural (X2), Keadilan Distributif (X1)

b. Dependent Variable: Perilaku Kerja Kontraproduktif (Z) Sumber: Hasil Pengolahan Data, 2020

Diketahui dari Tabel 2 bahwa hasil pengujian persamaan substruktur pertama berdasarkan uji ANOVA atau $\mathrm{F}$ test, diperoleh F hitung sebesar 5,060 dengan tingkat signifikan 0,003. Oleh karena probabilitas jauh lebih kecil dari pada 0,05 $(0,003<0,05)$. Dari hasil pengujian tersebut maka $\mathrm{H}_{0}$ ditolak dan $\mathrm{H}_{1}$ diterima, maka artinya variabel bebasdari keadilan distributif $\left(\mathrm{X}_{1}\right)$, keadilan prosedural $\left(\mathrm{X}_{2}\right)$, dan keadilan interaksional $\left(\mathrm{X}_{3}\right)$

berpengaruh secara bersama-sama terhadap variabel terikat yaitu perilaku kerja kontraproduktif (Z) pada Dinas Sosial Provinsi Kalimantan Barat dan persamaan koefisien jalur pada substruktur pertama ini layak untuk dipergunakan.

2)Pengujian Koefisien Determinasi.

Dalam pengujian koefisien determinasi maka akan diketahui seberapa besar pengaruh variabel keadilan distributif $\left(\mathrm{X}_{1}\right)$, keadilan prosedural $\left(\mathrm{X}_{2}\right)$, dan keadilan interaksional $\left(\mathrm{X}_{3}\right)$ terhadap perilaku kerja kontraproduktif (Z) pada pegawai Dinas Sosial Provinsi 
Tabel 3

Koefisien Determinasi Persamaan Substruktur Pertama Model Summary

\begin{tabular}{|l|r|r|r|r|}
\hline Model & $\mathrm{R}$ & \multicolumn{1}{|c|}{ R Square } & Adjusted R Square & $\begin{array}{c}\text { Std. Error of the } \\
\text { Estimate }\end{array}$ \\
\hline 1 & $.397^{\mathrm{a}}$ & .158 & .127 & 3.854 \\
\hline
\end{tabular}

a. Predictors: (Constant), Keadilan Interaksional (X3), Keadilan Prosedural (X2), Keadilan Distributif (X1)

b. Dependent Variable: Perilaku Kerja Kontraproduktif (Z)

Sumber:Hasil Pengolahan Data, 2020

Diketahui dari Tabel 3 di atas bahwa nilai dari R-Square adalah sebesar 0,158, ini berarti bahwa pengaruh variabel keadilan distributif (X1), keadilan prosedural (X2), dan keadilan interaksional (X3) terhadap perilaku kerja kontraproduktif (Z) pada pegawai Dinsos Prov. Kalbar adalah sebesar 15,8\% dan sisanya sebesar $84,2 \%$ dipengaruhi oleh variabel lain. Nilai dari koefisien residu error term $(\varepsilon 1)$ dari substruktur pertama adalah:

$\varepsilon 1=1$ 圆 $=0,918.0=$

3) Uji Parsial.

Selanjutnya adalah pengujian pengaruh hipotesis yang pengujiannya dilakukan untuk melihat seberapa jauh pengaruh variabel bebas yang digunakan dalam penelitian ini dalam menerangkan variabel terikat. Adapun dari Tabel 1 di atas diketahui hasil pengujian hipotesis secara parsial adalah sebagai berikut:

a. Hasil pengujian parsial variabel keadilan distributif (X1) terhadap perilaku kerja kontraproduktif (Z).

Berdasarkan hasil uji t pada Tabel 1 diperoleh nilai signifikansi untuk variabel keadilan distributif (X1) sebesar 0,234, dimana nilai tersebut lebih besar dari 0,05, maka hipotesis H1 ditolak dan H0 diterima. Dengan demikian variabel keadilan distributif (X1) berpengaruh tidak signifikan terhadap variabel perilaku kerja kontraproduktif $(\mathrm{Z})$ pada pegawai Dinas Sosial Provinsi Kalimantan Barat.

b. Hasil pengujian parsial variabel keadilan prosedural (X2) terhadap perilaku kerja kontraproduktif (Z).

Berdasarkan hasil uji t pada Tabel 1 diperoleh nilai signifikansi untuk variabel keadilan prosedural (X2) sebesar 0,008, dimana nilai tersebut 
lebih kecil dari 0,05, maka hipotesis H1 dapat diterima dan H0 ditolak. Dengan demikian variabel keadilan prosedural (X2) berpengaruh signifikan terhadap variabel perilaku kerja kontraproduktif (Z) pada pegawai Dinas Sosial Provinsi Kalimantan Barat.

c. Hasil pengujian parsial variabel keadilan interaksional (X3) terhadap kepuasan kerja (Z). Berdasarkan hasil uji t pada Tabel 1 diperoleh nilai signifikansi untuk variabel keadilan interaksional (X3) sebesar 0,110, dimana nilai tersebut lebih besar dari 0,05, maka hipotesis H1 ditolak dan H0 diterima.

Dengan demikian variabel keadilan interaksional (X3) berpengaruh tidak signifikan terhadap variabel perilaku kerja kontraproduktif (Z) pada pegawai Dinas Sosial Provinsi Kalimantan Barat.

\section{b. Substruktur Kedua}

Analisis mengenai substruktur kedua dapat diketahui pada Tabel 4 berikut:

Tabel 4

Hasil Uji Hipotesis Persamaan Substruktur Kedua Coefficients $^{\mathrm{a}}$

\begin{tabular}{|c|c|c|c|c|c|c|}
\hline \multirow{2}{*}{\multicolumn{2}{|c|}{ Model }} & \multicolumn{2}{|c|}{$\begin{array}{l}\text { Unstandardized } \\
\text { Coefficients }\end{array}$} & \multirow{2}{*}{$\begin{array}{c}\text { Standardized } \\
\text { Coefficients }\end{array}$} & \multirow[b]{2}{*}{$\mathrm{t}$} & \multirow[b]{2}{*}{ Sig. } \\
\hline & & $\mathrm{B}$ & Std. Error & & & \\
\hline 1 & (Constant) & 6.398 & 3.052 & & 2.096 & .039 \\
\hline & Keadilan Distributif (X1) & .250 & .094 & .243 & 2.660 & .009 \\
\hline & Keadilan Prosedural (X2) & .179 & .065 & .250 & 2.762 & .007 \\
\hline & Keadilan Interaksional (X3) & .194 & .069 & .253 & 2.805 & .006 \\
\hline & $\begin{array}{l}\text { Perilaku Kerja } \\
\text { Kontraproduktif (Z) }\end{array}$ & -.119 & .041 & -.267 & -2.881 & .005 \\
\hline
\end{tabular}

a. Dependent Variable: Kepuasan Kerja (Y)

Sumber:Hasil Pengolahan Data, 2020

Dari Tabel 4 diketahui bahwa persamaan substruktur kedua adalah sebagai berikut: $\mathrm{Y}=0,243 \mathrm{X} 1+0,250 \mathrm{X} 2+0,253 \mathrm{X} 3-0,267 \mathrm{Z}+\varepsilon 2$.

1) Uji Pengaruh Simultan

Uji pengaruh simultan adalah untuk mengetahui seberapa jauh semua variabel bebas yang dimasukkan dalam model mempunyai pengaruh secara bersama-sama terhadap variabel terikat. Hasil pengujian dari hipotesis terlihat pada Tabel 5 sebagai berikut:

Tabel 5

Model ANOVA Persamaan Substruktur Kedua ANOVA $^{b}$ 


\begin{tabular}{|c|c|c|c|c|c|c|}
\hline \multicolumn{2}{|c|}{ Model } & Sum of Squares & $\mathrm{df}$ & Mean Square & $\mathrm{F}$ & Sig. \\
\hline \multirow[t]{3}{*}{1} & Regression & 120.186 & 4 & 30.047 & 14.565 & $.000^{\mathrm{a}}$ \\
\hline & Residual & 165.037 & 80 & 2.063 & & \\
\hline & Total & 285.224 & 84 & & & \\
\hline
\end{tabular}

Diketahui dari Tabel 5 bahwa hasil pengujian persamaan substruktur kedua berdasarkan uji ANOVA atau F test, diperoleh F hitung sebesar 14,565 dengan tingkat signifikan 0,000. Oleh karena probabilitas jauh lebih kecil dari pada $0,05(0,000<$ $0,05)$. Dari hasil pengujian tersebut maka HO ditolak dan H1 diterima, maka artinya variabel bebas dari keadilan distributif (X1), keadilan prosedural (X2), keadilan interaksional (X3) dan perilaku kerja kontraproduktif (Z) berpengaruh secara bersama-sama terhadap variabel terikat yaitu kepuasan kerja $(\mathrm{Y})$ pada pegawai Dinas Sosial Provinsi Kalimantan Barat. Model dari persamaan koefisien jalur pada substruktur kedua ini layak untuk dipergunakan.

2) Pengujian Koefisien Determinasi

Dalam pengujian koefisien determinasi, maka akan diketahui seberapa besar pengaruh variabel keadilan distributif $\left(\mathrm{X}_{1}\right)$, keadilan prosedural $\left(\mathrm{X}_{2}\right)$, keadilan interaksional $\left(\mathrm{X}_{3}\right)$ dan perilaku kerja kontraproduktif (Z) terhadap kepuasan kerja (Y) pada pegawai Dinas Sosial Provinsi Kalimantan Barat. Nilai koefisien determinasi $R$-Square terlihat padaTabel 6 berikut ini:

Tabel 6

Koefisien Determinasi Persamaan Substruktur Kedua Model Summary

\begin{tabular}{|l|r|r|r|r|}
\hline Model & $\mathrm{R}$ & R Square & Adjusted R Square & $\begin{array}{c}\text { Std. Error of the } \\
\text { Estimate }\end{array}$ \\
\hline 1 & $.649^{\mathrm{a}}$ & .421 & .392 & 1.436 \\
\hline
\end{tabular}

a. Predictors: (Constant), Perilaku Kerja Kontraproduktif (Z), Keadilan Interaksional (X3), Keadilan Prosedural (X2), Keadilan Distributif (X1)

b. Dependent Variable: Kepuasan Kerja (Y)

Sumber:Hasil Pengolahan Data, 2020

Diketahui dari Tabel 6 di atas, bahwa nilai dari R-Square adalah sebesar 0,421 yang artinya adalah bahwa pengaruh variabel keadilan distributif (X1), keadilan prosedural (X2), keadilan interaksional (X3) dan perilaku kerja kontraproduktif (Z) terhadap kepuasan kerja

(Y) pada pegawai Dinas Sosial Provinsi Kalimantan Barat adalah sebesar 42,1\% dan sisanya adalah sebesar $57,9 \%$ dipengaruhi oleh variabel lain. 
Selanjutnya adalah pengujian pengaruh hipotesis yang pengujiannya dilakukan untuk melihat seberapa jauh pengaruh variabel bebas yang digunakan dalam penelitian ini dalam menerangkan variabel terikat. Adapun dari Tabel 4 di atas, dapat diketahui hasil pengujian hipotesis secara parsial adalah sebagai berikut :

a. Hasil pengujian parsial variabel keadilan distributif (X1) terhadap kepuasan kerja (Y). Berdasarkan hasil uji t pada Tabel 4 diperoleh nilai signifikansi untuk variabel keadilan distributif (X1) sebesar 0,009, dimana nilai tersebut lebih kecil dari 0,05, maka hipotesis $\mathrm{H} 1$ dapat diterima dan $\mathrm{HO}$ ditolak. Dengan demikian variabel keadilan distributif $(\mathrm{X} 1)$ berpengaruh signifikan terhadap variabel kepuasan kerja $(\mathrm{Y})$ pegawai pada Dinas Sosial Provinsi Kalimantan Barat.

b. Hasil pengujian parsial variabel keadilan prosedural (X2) terhadap kepuasan kerja (Y). Berdasarkan hasil uji t pada Tabel 4 diperoleh nilai signifikansi untuk variabel keadilan prosedural (X2) sebesar 0,007, dimana nilai tersebut lebih kecil dari 0,05, maka hipotesis $\mathrm{H} 1$ dapat diterima dan $\mathrm{HO}$ ditolak. Dengan demikian variabel keadilan prosedural (X2) berpengaruh signifikan terhadap variabel kepuasan kerja (Y) pegawai pada Dinas Sosial Provinsi Kalimantan Barat.

c. Hasil pengujian parsial variabel keadilan interaksional (X2) terhadap kepuasan kerja (Y). Berdasarkan hasil uji t pada Tabel 4 diperoleh nilai signifikansi untuk variabel keadilan interaksional (X3) sebesar 0,006, dimana nilai tersebut lebih kecil dari 0,05, maka hipotesis $\mathrm{H} 1$ dapat diterima dan $\mathrm{H} 0$ ditolak. Dengan demikian variabel keadilan interaksional (X3) berpengaruh signifikan terhadap variabel kepuasan kerja (Y) pegawai pada Dinas Sosial Provinsi Kalimantan Barat.

d. Hasil pengujian variabel perilaku kerja kontraproduktif (Z) terhadap kepuasan kerja (Y). Berdasarkan hasil uji t pada Tabel 4.20 diperoleh nilai signifikansi untuk variabel perilaku kerja kontraproduktif (Z) sebesar 0,005, dimana nilai tersebut lebih kecil dari 0,05 , maka hipotesis $\mathrm{H} 1$ dapat diterima dan $\mathrm{HO}$ ditolak. Dengan demikian variabel perilaku kerja kontraproduktif (Z) berpengaruh signifikan terhadap variabel kepuasan kerja (Y) pada pegawai Dinas Sosial Provinsi Kalimantan Barat.

\section{Pengaruh Lngsung dan Pengaruh Tidak Langsung}

Adapun pengaruh langsung maupun tidak langsung adalah untuk mengetahui besarnya pengaruh variabel independent (bebas) terhadap variabel dependent (terikat) sehingga dapat diketahui tingkat pengaruh dari variabel tersebut, seperti terlihat pada Tabel 4.23 berikut ini: 
Tabel 7

Pengaruh Antar Variabel Penelitian

\begin{tabular}{|c|c|c|c|c|}
\hline \multirow{2}{*}{ Variabel Bebas } & \multirow{2}{*}{$\begin{array}{l}\begin{array}{c}\text { Perilaku Kerja } \\
\text { Kontraprodukt } \\
\text { if } \\
(\mathrm{Z})\end{array} \\
\begin{array}{l}\text { Pengaru } \\
\text { h } \\
\text { Langsun } \\
\text { g }\end{array} \\
\end{array}$} & \multicolumn{3}{|c|}{ Kepuasan Kerja (Y) } \\
\hline & & $\begin{array}{l}\text { Pengaru } \\
\text { h } \\
\text { Langsun } \\
\text { g }\end{array}$ & $\begin{array}{l}\text { Pengaruh } \\
\text { Tidak } \\
\text { Langsung }\end{array}$ & $\begin{array}{r}\text { Pengaru } \\
\text { hTotal }\end{array}$ \\
\hline \multicolumn{5}{|c|}{ Substruktur Pertama, $X_{1}, X_{2}, X_{3}$ terhadap Z } \\
\hline Keadilan Distributif $\left(\mathrm{X}_{1}\right)$ & $-0,130$ & & & \\
\hline Keadilan Prosedural $\left(\mathrm{X}_{2}\right)$ & $-0,285$ & & & \\
\hline Keadilan Interaksional $\left(\mathrm{X}_{3}\right)$ & $-0,172$ & & & \\
\hline \multicolumn{5}{|c|}{ Substruktur Kedua, $\mathrm{X}_{1}, \mathrm{X}_{2}, \mathrm{X}_{3}, \mathrm{Z}$ terhadap $\mathrm{Y}$} \\
\hline Keadilan Distributif $\left(\mathrm{X}_{1}\right)$ & & 0,243 & $-0,130 \times-0,267=0,035$ & 0,278 \\
\hline Keadilan Prosedural $\left(\mathrm{X}_{2}\right)$ & & 0,250 & $-0,285 \times-0,267=0,076$ & 0,326 \\
\hline Keadilan Interaksional $\left(\mathrm{X}_{3}\right)$ & & 0,253 & $-0,172 \times-0,267=0,046$ & 0,299 \\
\hline $\begin{array}{l}\text { Perilaku Kerja Kontraproduktif } \\
\text { (Z) }\end{array}$ & & $-0,267$ & & \\
\hline
\end{tabular}

Sumber:Hasil Pengolahan Data, 2020

Berdasarkan Tabel 7 pada substruktur pertama diketahui lintasan yang paling berpengaruh signifikan terhadap perilaku kerja kontraproduktif (Z) adalah penilaian keadilan prosedural (X2), dibandingkan keadilan distributif (X1) dan keadilan interaksional (X3). Sedangkan pada substruktur kedua yang paling berpengaruh signifikan terhadap kepuasan kerja (Y) adalah penilaian keadilan interaksional (X3) dibandingkan keadilan distributif (X1), keadilan prosedural (X2) dan perilaku kerja kontraproduktif (Z).

1. Analisis pengaruh keadilan distributif (X1) melalui perilaku kerja kontraproduktif (Z) terhadap kepuasan kerja (Y). Diketahui pengaruh langsung yang diberikan keadilan distributif $(X 1)$ terhadap kepuasan kerja $(Y)$ sebesar 0,243 , sedangkan pengaruh keadilan distributif (X1) melalui perilaku kerja kontraproduktif (Z) terhadap kepuasan kerja $(Y)$ adalah perkalian antara nilai beta $X 1$ terhadap $Z$ dengan nilai beta $Z$ terhadap $Y$ yaitu $-0,130 \times-0,267=0,035$. Maka pengaruh total yang diberikan keadilan distributif (X1) terhadap kepuasan kerja (Y) adalah pengaruh langsung ditambah dengan pengaruh tidak langsung yaitu $0,243+0,035=0,278$.

2. Analisis pengaruh keadilan prosedural (X2) melalui perilaku kerja kontraproduktif (Z) terhadap kepuasan kerja ( $Y$ ). Diketahui pengaruh langsung yang diberikan keadilan prosedural (X2) terhadap kepuasan kerja (Y) sebesar 0,250, sedangkan pengaruh keadilan prosedural (X2) melalui perilaku kerja kontraproduktif (Z) terhadap kepuasan kerja $(\mathrm{Y})$ adalah perkalian antara nilai beta $\mathrm{X} 2$ terhadap $\mathrm{Z}$ 
dengan nilai beta $Z$ terhadap $Y$ yaitu $-0,285 \times-0,267=0,076$. Maka pengaruh total yang diberikan keadilan prosedural $(\mathrm{X} 2)$ terhadap kepuasan kerja $(\mathrm{Y})$ adalah pengaruh langsung ditambah dengan pengaruh tidak langsung yaitu $0,250+0,076=$ 0,326 .

3. Analisis pengaruh keadilan interaksional (X3) melalui perilaku kerja kontraproduktif (Z) terhadap kepuasan kerja (Y). Diketahui pengaruh langsung yang diberikan keadilan interaksional $(\mathrm{X} 3$ ) terhadap kepuasan kerja $(\mathrm{Y})$ sebesar 0,253 , sedangkan pengaruh keadilan interaksional (X3) melalui perilaku kerja kontraproduktif (Z) terhadap kepuasan kerja $(\mathrm{Y})$ adalah perkalian antara nilai beta $\mathrm{X} 3$ terhadap $\mathrm{Z}$ dengan nilai beta $Z$ terhadap $Y$ yaitu $-0,172 \times-0,267=0,046$. Maka pengaruh total yang diberikan keadilan interaksional $(\mathrm{X} 3)$ terhadap kepuasan kerja $(\mathrm{Y})$ adalah pengaruh langsung ditambah dengan pengaruh tidak langsung yaitu 0,253+0,046=0,299.

Z

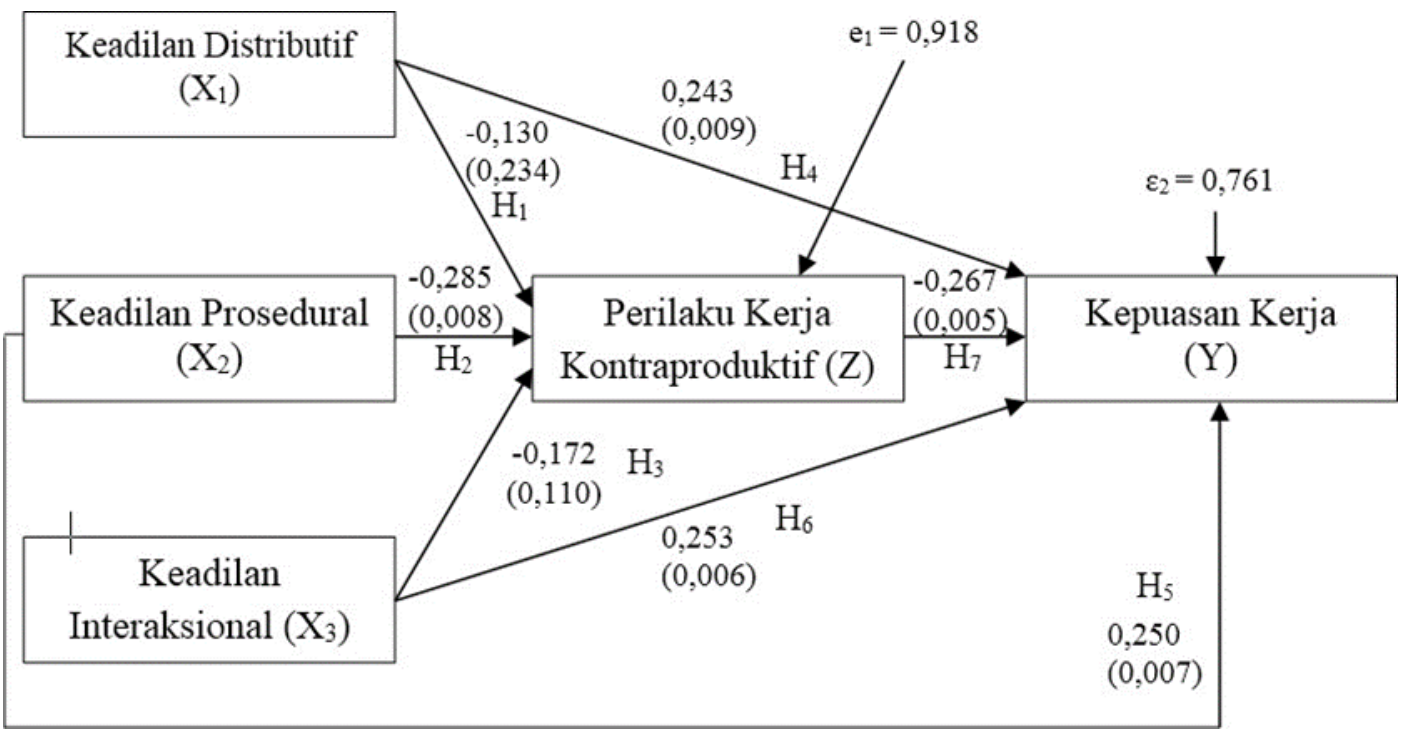

Gambar 2

PEMBAHASAN

Gambar Struktur Analisis Jalur (Path Analysis)

\section{Pengaruh Keadilan Distributif Terhadap Perilaku Kerja Kontraproduktif pada Pegawai Dinas Sosial Provinsi Kalimantan Barat.}

Berdasarkan hasil pengujian hipotesis pertama, diketahui bahwa keadilan distributif berpengaruh negatif dan tidak signifikan terhadap perilaku kerja kontraproduktif pada pegawai Dinas Sosial Provinsi Kalimantan Barat. Hal ini berdasarkan nilai koefisien jalur keadilan distributif yaitu sebesar -0,130 dengan nilai signifikansi sebesar 0,234 yang lebih besar dari 0,05. Berdasarkan hasil tersebut, maka hipotesis pertama yaitu keadilan distributif berpengaruh negatif dan tidak signifikan terhadap perilaku kerja kontraproduktif pada pegawai Dinas Sosial Provinsi Kalimantan Barat ditolak. Keadilan 
distributif berkaitan dengan persepsi karyawan terhadap hasil yang telah mereka terima dari organisasi. Sehingga organisasi harus mampu menciptakan keadilan, agar karyawan merasa bahwa mereka telah menerima hasil dari pekerjaannya dengan adil. Keadilan yang didapatkan oleh karyawan dianggap sebagai perbandingan antara hasil dari komitmen yang telah mereka buat serta hasil dari penghargaan, tugas dan tanggung jawab terhadap pekerjaannya. Ketika penghargaan dialokasikan kepada

\section{Pengaruh Keadilan Prosedural Terhadap Perilaku Kerja Kontraproduktif pada Pegawai Dinas Sosial Provinsi Kalimantan Barat.}

Berdasarkan hasil pengujian hipotesis kedua, diketahui bahwa keadilan prosedural berpengaruh negatif dan signifikan terhadap perilaku kerja kontraproduktif pada pegawai Dinas Sosial Provinsi Kalimantan Barat. Hal ini berdasarkan nilai koefisien jalur keadilan prosedural yaitu sebesar $-0,285$ dengan nilai signifikansi sebesar 0,008 yang lebih kecil dari 0,05 . Berdasarkan hasil tersebut, maka hipotesis kedua yaitu keadilan prosedural berpengaruh negatif dan signifikan terhadap perilaku kerja kontraproduktif pada pegawai Dinas Sosial Provinsi Kalimantan Barat diterima. Keadilan prosedural kerja. Hal tersebut dapat menyebabkan karyawan merasa tidak puas, maka cenderung melakukan perilaku kerja kontraproduktif serta menurunkan kinerja dan merugikan organisasi. Hal tersebut dibuktikan juga dalam penelitian yang dilakukan oleh Nurfianti \& Handoyo (2013) yang menemukan bahwa keadilan distributif memiliki hubungan yang negatif terhadap perilaku kerja kontraproduktif. Penelitian tersebut menunjukkan bahwa semakin tinggi keadilan distributif yang diberikan organisasi, maka perilaku kerja kontraproduktif akan semakin rendah.

Berdasarkan hasil pengujian hipotesis kesembilan, diketahui bahwa perilaku kerja kontraproduktif tidak berperan sebagai variabel yang memediasi pengaruh keadilan prosedural terhadap kepuasan kerja pegawai pada Dinas Sosial Provinsi Kalimantan Barat. Hal ini berdasarkan nilai pengaruh langsung keadilan prosedural terhadap kepuasan kerja sebesar 0,250 lebih besar dari nilai pengaruh tidak langsung keadilan prosedural terhadap kepuasan kerja melalui perilaku kerja kontraproduktif sebesar 0,076. Berdasarkan hasil tersebut, maka hipotesis kedelapan yaitu perilaku kerja kontraproduktif tidak berperan sebagai variabel yang memediasi pengaruh keadilan prosedural terhadap kepuasan kerja pegawai pada Dinas Sosial Provinsi Kalimantan Barat. Keadilan prosedural menurut Robbins \& Judge (2008), didefinisikan sebagai keadilan yang dirasakan dari proses yang digunakan untuk menentukan distribusi imbalan.

\section{KESIMPULAN}

Berdasarkan hasil penelitian dan pembahasan mengenai pengaruh keadilan organisasi terhadap perilaku kerja kontraproduktif dan dampaknya pada kepuasan kerja pada pegawai Dinas Sosial Provinsi Kalimantan Barat, dapat ditarik kesimpulan sebagai berikut: 
1. Keadilan Distributif berpengaruh negatif dan tidak signifikan terhadap perilaku kerja kontraproduktif pada pegawai Dinas Sosial Provinsi Kalimantan Barat. Hal ini karena keadilan distributif yang diberikan instansi kepada karyawan tidak mampu mendorong karyawan untuk melakukan pekerjaan yang menyimpang dari aturan kerja di Dinas Sosial Provinsi Kalimantan Barat.

2. Keadilan Prosedural berpengaruh negatif dan signifikan terhadap perilaku kerja kontraproduktif pada pegawai Dinas Sosial Provinsi Kalimantan Barat. Hal ini karena keadilan prosedural yang diberikan instansi kepada karyawan tidak mampu mendorong karyawan untuk melakukan pekerjaan yang menyimpang dari aturan kerja di Dinas Sosial Provinsi Kalimantan Barat.

3. Keadilan Interaksional berpengaruh negatif dan tidak signifikan terhadap perilaku kerja kontraproduktif pada pegawai Dinas Sosial Provinsi Kalimantan Barat. Hal ini karena keadilan interaksional yang diberikan instansi kepada karyawan tidak mampu mendorong karyawan untuk melakukan pekerjaan yang menyimpang dari aturan kerja di Dinas Sosial Provinsi Kalimantan Barat.

4. Keadilan Distributif berpengaruh positif dan signifikan terhadap kepuasan kerja pada pegawai Dinas Sosial Provinsi Kalimantan Barat. Hal ini karena keadilan distributif yang diberikan instansi kepada karyawan mampu mendorong karyawan untuk merasa puas bekerja di Dinas Sosial Provinsi Kalimantan Barat.

5. Keadilan Prosedural berpengaruh positif dan signifikan terhadap kepuasan kerja pada pegawai Dinas Sosial Provinsi Kalimantan Barat. Hal ini karena keadilan prosedural yang diberikan instansi kepada karyawan mampu mendorong karyawan untuk merasa puas bekerja di Dinas Sosial Provinsi Kalimantan Barat.

6. Keadilan Interaksional berpengaruh positif dan signifikan terhadap kepuasan kerja pada pegawai pada Dinas Sosial Provinsi Kalimantan Barat. Hal ini karena keadilan interaksional yang diberikan instansi kepada karyawan mampu mendorong karyawan untuk merasa puas bekerja di Dinas Sosial Provinsi Kalimantan Barat.

7. Perilaku Kerja Kontraproduktif berpengaruh negatif dan signifikan terhadap kepuasan kerja pada pegawai pada Dinas Sosial Provinsi Kalimantan Barat. Hal ini karena perilaku kerja kontraproduktif yang dilakukan karyawan, karyawan merasa puas terhadap kegiatan yang dilakukan selama bekerja di Dinas Sosial Provinsi Kalimantan Barat.

8. Perilaku Kerja Kontraproduktif tidak berpengaruh sebagai variabel yang memediasi pengaruh keadilan distributif terhadap kepuasan kerja pada pegawai pada Dinas Sosial Provinsi Kalimantan Barat. Artinya bahwa karyawan tidak merasakan perilaku kerja kontraproduktif saat bekerja, sehingga keadilan distributif yang diberikan instansi mampu mendorong karyawan merasa puas saat bekerja di Dinas Sosial Provinsi Kalimantan Barat.

9. Perilaku Kerja Kontraproduktif tidak berpengaruh sebagai variabel yang memediasi pengaruh keadilan prosedural terhadap kepuasan kerja pada pegawai pada Dinas Sosial Provinsi Kalimantan Barat. Artinya bahwa karyawan tidak merasakan perilaku 
kerja kontraproduktif saat bekerja, sehingga keadilan prosedural yang diberikan instansi mampu mendorong karyawan merasa puas saat bekerja di Dinas Sosial Provinsi Kalimantan Barat.

10. Perilaku Kerja Kontraproduktif tidak berpengaruh sebagai variabel yang memediasi pengaruh keadilan interaksional terhadap kepuasan kerja pada pegawai pada Dinas Sosial Provinsi Kalimantan Barat. Artinya bahwa karyawan tidak merasakan perilaku kerja kontraproduktif saat bekerja, sehingga keadilan interaksional yang diberikan instansi mampu mendorong karyawan merasa puas saat bekerja di Dinas Sosial Provinsi Kalimantan Barat.

\section{REKOMENDASI}

Berdasarkan beberapa kesimpulan yang telah disampaikan di atas, maka terdapat beberapa hal yang disarankan sebagai berikut :

1. Diharapkan pimpinan instansi/Dinas Sosial Provinsi Kalimantan Barat dapat memperbaiki dan lebih meningkatkan lagi penerapan keadilan organisasional yang ada. Hal ini diperlukan untuk mencegah dan meminimalisir penyimpangan properti, penyimpangan produksi, penyimpangan politik dan agresi individu yang ada dalam diri pegawai ketika bekerja.

2. Dinas Sosial Provinsi Kalimantan Barat dapat mempertahankan kebijakan yang selama ini telah dilakukan terhadap para pegawainya bahkan jika memungkinkan untuk terus ditingkatkan lagi, sehingga kepuasan kerja pegawai bisa semakin meningkat. Dan itu akan berimplikasi kepada peningkatan kinerja yang akan dicapai. Dari ke tiga variabel keadilan organisasional yang di uji, yaitu keadilan disributif, keadilan prosedural dan keadilan interaksional semuanya mempunyai pengaruh positif dan signifikan terhadap kepuasan kerja. Seluruh aspek keadilan organisasional tersebut bisa berperan secara sama dalam meningkatkaan kepuasan kerja pegawai.

3. Untuk penelitian selanjutnya dapat mengembangkan dengan variabel lain yang menjadi perantara atau memperkuat pengaruh keadilan organisasional terhadap perilaku kerja kontraproduktif serta dampaknya pada kepuasan kerja. Variabel tersebut bisa jadi faktor dari dalam organisasi seperti komunikasi organisasi atau variabel dari dalam pribadi karyawan seperti karakteristik personal. Variabel-variabel tersebut dapat diperoleh dari berbagai literatur jurnal atau penelitian terdahulu. 


\section{DAFTAR PUSTAKA}

Anderson, N. (2005). Handbook of Industrial, Work and Organizational Psychology. Vol.1 : London : Sage.

Antari, G. A. E. J., \& Suwandana, I. G. M. (2016). Pengaruh lingkungan kerja, keadilan organisasional dan komitmen organisasional terhadap kepuasan kerja karyawan. EJournal Manajenen Unud, 5(7), 4518-4544.

Atalay, C. G., \& Ozler, D. E. (2013). A Research to Determine the Relationship between Organizational Justice and Psychological Ownership among Non Family Employees in a Family Business. Social and Behavioral Sciences, 99, 247-256.

Colquitt, J. A. (2001). On the dimensionality of organizational justice a construct validation of a measure. Journal of Applied Psychology, 86(3), 386-400.

Colquitt, J. A., \& Judge, T. A. (2004). Organizational justice and stress the mediating role of work family conflict. Journal of Applied Psychology, 89(3), 395-404.

Dundar, T., \& Tabancali, E. (2012). The relationship between organizational justice perceptions and job satisfaction levels.

Gruys, M. L., dan Sackett, P. R. (2003). Investigating the dimensionality of counterproductive work behavior. International Journal of Selection and Assessment, 11 (1): 30-42.

Guven, B., \& Gursoy, A. (2014). A study on the organizational justice and organizational citizenship dimensions and behaviors. Beykent University Journal of Social Sciences, 7(1), 92-110.

Irwandi, S. A., \& Puspitadewi, P. (2012). Hubungan keadilan organisasional dan kecenderungan pegawai dengan moderating kualitas pengendalian internal. The Indonesian Accounting Review, 2(2), 159-172.

Josef, E. S. (2017). Pengaruh dimensi keadilan organisasional terhadap perilaku kerja kontraproduktif pada karyawan. Jurnal IImu Manajemen, 5(1), 1-9.

Kaddarudin, Abd. Rahman Kadir, Ria Mardiana Y, (2012). Pengaruh Keadilan Distributif, Keadilan Prosedural Dan Keadilan Interaksional Terhadap Kepuasan Pegawai Pajak di Kota Makassar. Manajemen dan Keuangan. Universitas Hasanuddin: Makassar.

Kanten, P., \& Ulker, F. E. (2013). The effect of organizational climate on counterproductive behaviors: an empirical study on the employees of manufacturing enterprises. The Macrotheme Review, 2(4), 144-160. 
Lau, V. C. S., Au, W. T., dan Ho, J. M. C. (2003). A qualitative and quantitative review of antecedents of counterproductive behavior in organizations. Journal of Business and Psychology, 18 (1): 73-99.

Lubis, Z., \& Weldali, L. M. S. A. (2016). Organizational justice and counterproductive work behavior moderating effect of power distance. International Journal in Management and Social Science. 4(4), 239-251.

Muhammad., Fajrianthi. (2013). Pengaruh Keadilan Organisasi Terhadap Intensi Turnover Pada Karyawan Arsitek dan Konstruktor di Surabaya. Jurnal Psikologi Industri dan Organisasi, Volume 2, No. 2, pp. 83-89.

Oge, G. M., Ifeanyi, E. O., \& Gozie, C. (2015). Examining the link between organizational justice and counterproductive work behavior. Journal of Business and Management Studies, 1(2), 1-10.

Priansa, Donni Juni (2016). Perencanaan \& Pengembangan SDM, Cetakan Kedua. Bandung: Alfabeta.

Ratnawati, \& Amri. (2013). Pengaruh Keadilan Organisasional, Kepercayaan Pada Atasan Terhadap Perilaku Kewargaan Organisasi (Organizational Citizenship Behavior). Jurnal Ekonomi Manajemen dan Bisnis. Volume 1 Nomor 1 Juni, Halaman 56-73.

Rayadi. (2012). Faktor sumber daya manusia yang meningkatkan kinerja karyawan dan perusahaan di kalbar. Jurnal Ekonomi Sosial, 8(2), 114-119.

Robbins, Stephen P. \& Judge, Timothy A. (2013). Organizational Behavior, Edition 15. Pearson.

Rusdi, Z. M. (2015). Ananlisis perilaku kerja kontra produktif pada pegawai negeri sipil di bandar lampung. Jurnal Bisnis dan Manajemen, 10(2), 164- 178.

Wahyuni, S., \& Nugraheni, H. (2016). Pengaruh narsisme dan job stressor pada perilaku kerja kontra produktif dengan respon emosional negative (anger) sebagai mediator. Jurnal Bisnis dan Manajemen. 16(2), 49-66.

Winurini, S. (2014). Mengatasi perilaku kontraproduktif aparatur negara melalui sistem remunerasi (sebuah review mengenai keadilan organisasi). Aspirasi, 5(1), 35-49. 